\title{
Role of Ionotropic Glutamate Receptors in Long-Term Potentiation in Rat Hippocampal CA1 Oriens-Lacunosum Moleculare Interneurons
}

\author{
Iris Oren, ${ }^{1}$ Wiebke Nissen, ${ }^{2}$ Dimitri M. Kullmann, ${ }^{1}$ Peter Somogyi, ${ }^{3}$ and Karri P. Lamsa ${ }^{2}$ \\ ${ }^{1}$ Institute of Neurology, University College London, London WC1N 3BG, United Kingdom, ${ }^{2}$ Department of Pharmacology, Oxford University, Oxford 0X1 \\ 3QT, United Kingdom, and ${ }^{3}$ Medical Research Council Anatomical Neuropharmacology Unit, Oxford University, Oxford OX1 3HT, United Kingdom
}

\begin{abstract}
Some interneurons of the hippocampus exhibit NMDA receptor-independent long-term potentiation (LTP) that is induced by presynaptic glutamate release when the postsynaptic membrane potential is hyperpolarized. This "anti-Hebbian" form of LTP is prevented by postsynaptic depolarization or by blocking AMPA and kainate receptors. Although both AMPA and kainate receptors are expressed in hippocampal interneurons, their relative roles in anti-Hebbian LTP are not known. Because interneuron diversity potentially conceals simple rules underlying different forms of plasticity, we focus on glutamatergic synapses onto a subset of interneurons with dendrites in stratum oriens and a main ascending axon that projects to stratum lacunosum moleculare, the oriens-lacunosum moleculare (0-LM) cells. We show that anti-Hebbian LTP in 0-LM interneurons has consistent induction and expression properties, and is prevented by selective inhibition of AMPA receptors. The majority of the ionotropic glutamatergic synaptic current in these cells is mediated by inwardly rectifying $\mathrm{Ca}^{2+}$-permeable AMPA receptors. Although GluR5-containing kainate receptors contribute to synaptic currents at high stimulus frequency, they are not required for LTP induction. Glutamatergic synapses on 0-LM cells thus behave in a homogeneous manner and exhibit LTP dependent on $\mathrm{Ca}^{2+}$-permeable AMPA receptors.
\end{abstract}

Key words: inhibition; GABAergic; kainate; network; plasticity; interneuron

\section{Introduction}

Hippocampal GABAergic interneurons show extensive diversity as revealed by physiological and anatomical analyses (Klausberger and Somogyi, 2008). Interneuron plasticity also exhibits a high degree of diversity. Although long-term plasticity in hippocampal pyramidal cells obeys relatively stereotypical rules, several different forms of long-term potentiation (LTP) and longterm depression (LTD) have been described in GABAergic interneurons (Buzsáki and Eidelberg, 1982; Ouardouz and Lacaille, 1995; McMahon and Kauer, 1997; Cowan et al., 1998; Maccaferri et al., 1998; Laezza et al., 1999; Christie et al., 2000; Alle et al., 2001; Perez et al., 2001; Laezza and Dingledine, 2004; Lei and McBain, 2004; Lamsa et al., 2005, 2007a).

NMDA receptor (NMDAR)-independent LTP in hippocampal interneurons has recently received considerable attention (Perez et al., 2001; Lapointe et al., 2004; Lamsa et al., 2007a). Induction of one such form of LTP is prevented by the AMPA and kainate receptor antagonist 2,3-dihydroxy-6-nitro-7-sulfamoylbenzo[f] quinoxaline-2,3-dione (NBQX) (Lamsa et al., 2007a;

Received July 10, 2008; revised Nov. 19, 2008; accepted Nov. 26, 2008.

This work was supported by The Wellcome Trust and the Medical Research Council. We are grateful to Drs. Ole Paulsen and Sari Lauri for their comments on this manuscript, and Kristina Detzner and David Roberts for expert technical assistance. We thank Dr. Jozsef Somogyi for his help with confocal microscopy.

Correspondence should be addressed to Karri P. Lamsa, Department of Pharmacology, Oxford University, Mansfield Road, 0xford 0X1 30T, UK. E-mail: karri.lamsa@pharm.ox.ac.uk.

DOI:10.1523/JNEUROSCI.3251-08.2009

Copyright $\odot 2009$ Society for Neuroscience $\quad$ 0270-6474/09/290939-12\$15.00/0
Kullmann and Lamsa, 2008). $\mathrm{Ca}^{2+}$-permeable AMPA receptors (CP-AMPARs) are common in many GABAergic interneurons (Jonas et al., 1994; Geiger et al., 1995; Racca et al., 1996; Catania et al., 1998; Tóth and McBain, 1998; Topolnik et al., 2005; Lamsa et al., 2007a). These receptor channels show a marked inward rectification (Jonas et al., 1994; Bowie and Mayer, 1995; Kamboj et al., 1995; Koh et al., 1995), which can explain the finding that LTP at synapses on some interneurons in the CA1 area is most successfully elicited by presynaptic activity when the postsynaptic membrane potential is hyperpolarized (Lamsa et al., 2007a). The phenomenon has been termed anti-Hebbian LTP to distinguish it from Hebbian NMDA receptor-dependent LTP (Kullmann and Lamsa, 2007). Although $\mathrm{Ca}^{2+}$ influx via CP-AMPARs provides a simple explanation for anti-Hebbian LTP induction, NBQX also blocks kainate receptors (Bureau et al., 1999; Cossart et al., 2002; Goldin et al., 2007), which are abundant in hippocampal interneurons (Cossart et al., 1998, 2002; Frerking et al., 1998; Bureau et al., 1999; Paternain et al., 2000; Rogawski et al., 2003; Yang et al., 2006; Goldin et al., 2007). Kainate receptors can also exhibit marked inward rectification and calcium permeability (Egebjerg and Heinemann, 1993; Köhler et al., 1993; Bowie and Mayer, 1995).

Dissecting the relative roles of AMPARs and kainate receptors in anti-Hebbian LTP is potentially confounded by the extensive interneuron diversity that exists in the hippocampus (Somogyi and Klausberger, 2005). We have therefore focused on a single interneuron type: oriens-lacunosum moleculare (O-LM) cells in 
the CA1 area (Lacaille et al., 1987; Blasco-Ibáñez and Freund, 1995; Sik et al., 1995; Yanovsky et al., 1997; Ali and Thomson, 1998). We find that glutamatergic synapses made by axons in the CA1 stratum (s.) oriens onto O-LM cells show anti-Hebbian LTP with remarkably uniform properties. Although GluR5containing kainate receptors contribute to EPSCs, they are not necessary for LTP induction, which is fully prevented by blockade of CP-AMPARs. Restricting attention to an identified pathway within the hippocampal inhibitory circuitry thus reveals a far more uniform pattern of synaptic physiology, pharmacology, and plasticity than seen in the population of interneurons as a whole.

\section{Materials and Methods Hippocampal slices}

Three- to four-week-old male Sprague Dawley rats were killed by cervical dislocation and decapitated. The brain was rapidly removed and placed in ice-cold $\left(0\right.$ to $\left.+4^{\circ} \mathrm{C}\right)$ sucrose cutting solution containing the following (in mM): 75 sucrose, $87 \mathrm{NaCl}, 2.5 \mathrm{KCl}, 0.5 \mathrm{CaCl}_{2}, 7 \mathrm{MgCl}_{2}, 1.0 \mathrm{NaH}_{2} \mathrm{PO}_{4}$, $25 \mathrm{NaHCO}_{3}, 25$ glucose, $\mathrm{pH} 7.4$, bubbled with $95 \% \mathrm{O}_{2} / 5 \% \mathrm{CO}_{2}$. Transverse hippocampal slices ( $350 \mu \mathrm{m}$ thickness) were cut using a vibrating microtome (Leica VT 1000S; Leica Microsystems). Slices were kept submerged at $32^{\circ} \mathrm{C}$ in the sucrose solution for $20-25$ min before being transferred to an interface chamber in which they were maintained in Earle's balanced salt solution (Invitrogen) with $3 \mathrm{mM} \mathrm{Mg}^{2+}$ and $1 \mathrm{mM} \mathrm{Ca}^{2+}$ at room temperature $\left(20-25^{\circ} \mathrm{C}\right)$ for at least $60 \mathrm{~min}$ before starting experiments.

Hippocampal slices were placed in a recording chamber (Luigs \& Neumann) mounted on the stage of an upright microscope (Olympus BX51WI), in which they were held under a nylon mesh grid and superfused at $3-5 \mathrm{ml} \mathrm{min}^{-1}$ with artificial CSF (ACSF) at $31-33^{\circ} \mathrm{C}$. The ACSF contained the following (in $\mathrm{mm}$ ): $119 \mathrm{NaCl}, 2.5 \mathrm{KCl}, 2.5 \mathrm{CaCl}_{2}, 1.3$ $\mathrm{MgSO}_{4}, 1.25 \mathrm{NaH}_{2} \mathrm{PO}_{4}, 25 \mathrm{NaHCO}_{3}, 11$ glucose, final $\mathrm{pH} 7.4$ (equilibrated with $95 \% \mathrm{O}_{2} / 5 \% \mathrm{CO}_{2}$ ). A cut was made between the $\mathrm{CA} 3$ and $\mathrm{CA} 1$ subfields to prevent the spread of bursting activity. Slices were visualized using a $20 \times$ immersion objective with $2-4 \times$ zoom and infrared differential interference contrast (DIC) optics.

\section{Electrophysiology}

Somatic perforated-patch recordings were made from neurons in CA1 s. oriens and alveus. Electrodes were made from borosilicate glass capillaries [GC150F; Harvard Apparatus] pulled on a Sutter microelectrode puller. Pipette resistance was typically $8-18 \mathrm{M} \Omega$ for perforated-patch and 4-7 M $\Omega$ for whole-cell recordings. A Multiclamp 700B amplifier was used for recording (Molecular Devices). Infrared DIC images of the cell at different magnification $(20,40$, and $80 \times)$ were obtained with a CCD camera (Till Photonics) during electrophysiological experiments. Gramicidin stock solution $\left(100 \mathrm{mg} \mathrm{ml}^{-1}\right.$; Sigma-Aldrich) was prepared in dimethyl sulfoxide daily. The pipette filling solution containing gramicidin was prepared by diluting the stock solution 1:1000 in potassium gluconate pipette solution. The pipette solution contained the following (in $\mathrm{mM}$ ): 145 potassium gluconate, $8 \mathrm{NaCl}, 20-25 \mathrm{KOH}$-HEPES, 0.2 EGTA, and 1-5 5-lidocaine $N$-ethyl bromide (QX-314 Br), pH 7.2; osmolarity, $295 \mathrm{mOsm} \mathrm{L}^{-1}$. The gramicidin-containing solution was sonicated several times for short periods (3-5 s) every $20 \mathrm{~min}$, and the gramicidin-containing pipette solution was discarded after $1 \mathrm{~h}$. The electrode tip was filled with gramicidin-free filtered potassium gluconate solution. The series resistance was continuously monitored throughout the experiment, and recordings were started when it was $<150 \mathrm{M} \Omega$. Bridge balance and pipette capacitance compensation were adjusted throughout the recordings. The presence of QX-314 in the filling solution allowed for detection of inadvertent patch rupture. Suprathreshold depolarizing current steps were injected intermittently to evoke action potentials. Failure to generate action potentials indicated membrane rupture in which case the experiment was aborted.

On completion of perforated-patch recordings, the pipette was slowly retracted under infrared DIC observation. Once the pipette detached from the cell, it was rapidly withdrawn from the slice. Next, the same cell was approached with a new pipette and repatched in whole-cell configuration. Infrared images obtained during the perforated-patch recording and the whole-cell recordings were compared, in order to verify that the same cell was repatched (supplemental Fig. 1, available at www.jneurosci. org as supplemental material).

The whole-cell filling solution contained the following (in $\mathrm{mM}$ ): 135 $\mathrm{CsCl}, 10 \mathrm{KOH}$-HEPES, $10 \mathrm{BAPTA}, 8 \mathrm{NaCl}, 2 \mathrm{Mg}$-ATP, $0.3 \mathrm{GTP}$, and 5 QX-314 Br, pH 7.2, 290 mOsm. Spermine tetrahydrochloride (0.5 mM; Tocris) was included in the filling solution to maintain polyaminemediated rectification of AMPA/kainate receptors during whole-cell recording. In addition, Neurobiotin ( $0.3-0.5 \%$; Alomone Labs) or biocytin $(0.5 \%$; Sigma-Aldrich) was included in the solution for post hoc anatomical analysis of cells. Capacitance compensation was applied in the cell-attached configuration before membrane rupture. Series resistance was not compensated during voltage-clamp recordings, but regularly monitored with small hyperpolarizing voltage steps $(-5 \mathrm{mV})$. The series resistance at the start of whole-cell voltage-clamp experiments was $19.3 \pm 1.1 \mathrm{M} \Omega(n=11)$ and changed by $<5 \mathrm{M} \Omega$ during the recordings. Data were not corrected for junction potentials.

Stimulation and data acquisition. Monosynaptic EPSPs or EPSCs were evoked by alternately stimulating in the s. oriens/alveus in area CA1 at $0.067 \mathrm{~Hz}$ via two concentric bipolar electrodes (outer diameter, $125 \mu \mathrm{m}$; FHC), connected to constant current isolated stimulators (DS3; Digitimer; 20-200 $\mu \mathrm{A}$; duration, $50 \mu \mathrm{s}$ ). The stimulators were controlled by a custom data acquisition program (LabView; National Instruments) or by pClamp 10 software (Molecular Devices). Evoked EPSPs were recorded from the resting membrane potential or in some experiments during a brief $(500 \mathrm{~ms})$ hyperpolarizing step $(5-10 \mathrm{mV})$ to avoid action potential generation. For LTP induction, one of the pathways was stimulated at $100 \mathrm{~Hz}$ for $1 \mathrm{~s}$, delivered twice with a $20 \mathrm{~s}$ interval. Simultaneously, the postsynaptic cell was voltage clamped (1200-2000 ms) at -70 to $-90 \mathrm{mV}$ or at $0 \mathrm{mV}$ (somatic potential). The pulse duration was longer than the stimulation train to keep the postsynaptic cell clamped during possible polysynaptic activity after the train. In the $1 \mathrm{~Hz}$ pairing protocol, the cell was stepped in voltage-clamp mode from -60 to $0 \mathrm{mV}$ (somatic potential) for $300 \mathrm{~ms}$, and a single presynaptic stimulus was delivered concomitant to the depolarizing step (Lamsa et al., 2005). Voltage steps to $0 \mathrm{mV}$ were accompanied by repetitive firing of action currents (supplemental Fig. 2, available at www.jneurosci.org as supplemental material). No series resistance compensation was used in voltage clamp. The voltage error resulting from perforated-patch series resistance was estimated and added to the voltage step to depolarize the somatic membrane potential to $0 \mathrm{mV}$. The series resistance was calculated from brief (100-200 ms) depolarizing steps with and without bridge balance compensation. In whole-cell recordings, EPSC currentvoltage relationships were estimated over a postsynaptic membrane potential range from -90 to $+60 \mathrm{mV}$ using $500 \mathrm{~ms}$ steps in voltage-clamp mode.

Miniature EPSCs (mEPSCs) were recorded in 120 s sweeps, with the seal test monitored in between sweeps. The first recordings were made 15 min after breaking through into the whole-cell configuration to allow for stabilization of the cell input resistance $(280 \pm 45 \mathrm{M} \Omega ; n=14)$. At least $6 \mathrm{~min}$ of recording were used for the analyses in each condition. To look for mEPSC rectification 120 -s-long recording periods were alternately obtained at $-60 \mathrm{mV}$ and at +40 to $+50 \mathrm{mV}$. When the cell was clamped at depolarized potentials, the recording was started with a 5-20 s delay to allow for relaxation of voltage-activated currents and a stable holding current.

In all recordings, data were low-pass filtered $(4-5 \mathrm{kHz})$ and acquired at $10-20 \mathrm{kHz}$ on a PC for off-line analysis. Data were analyzed using LabView, pClamp 10, or in Igor Pro (Wavemetrics).

Drugs. The GABA receptor blockers picrotoxin (100 $\mu \mathrm{M})$ and $(2 S)-3-$ [[(1S)-1-(3,4-dichlorophenyl)ethyl] amino-2-hydroxypropyl] (phenylmethyl)phosphinic acid (CGP55845) (1 $\mu \mathrm{M})$ were routinely added to the extracellular solution in all experiments. Where indicated, the NMDA receptor antagonist DL-2-amino-5-phosphonovaleric acid (DL-APV) $(100 \mu \mathrm{M})$ was also included. Other drugs were applied via superfusion $(3-5 \mathrm{ml} / \mathrm{min})$. Tetrodotoxin (TTX) $(1 \mu \mathrm{M})$ was present during mEPSC 
A
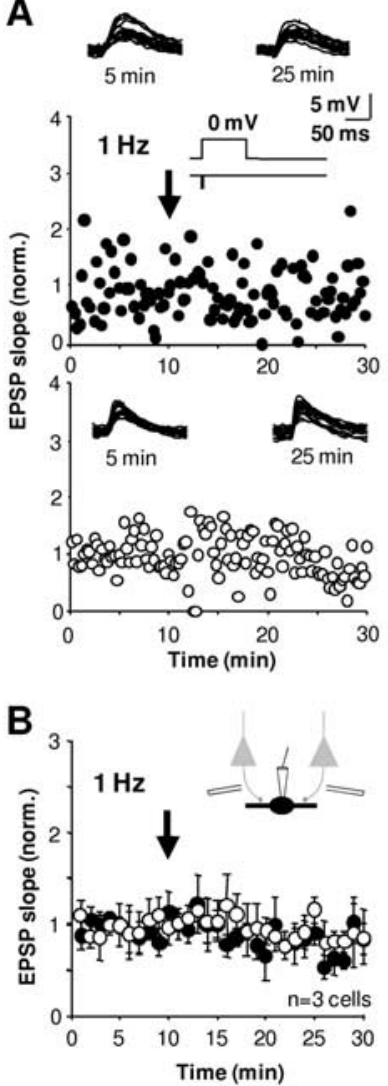

C
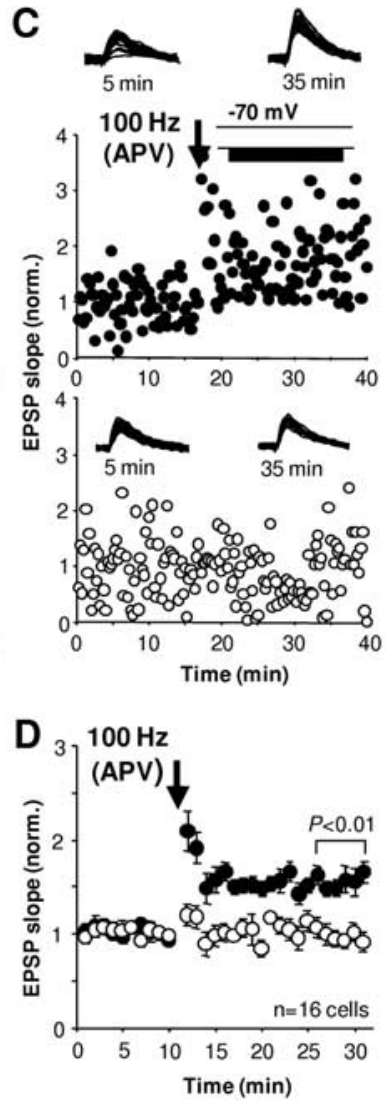

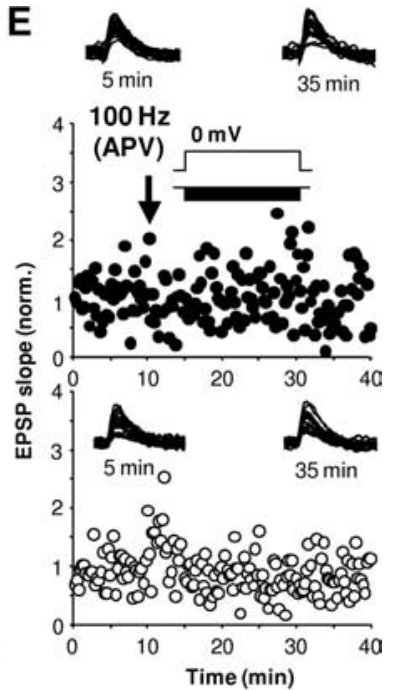

$\mathbf{F}$

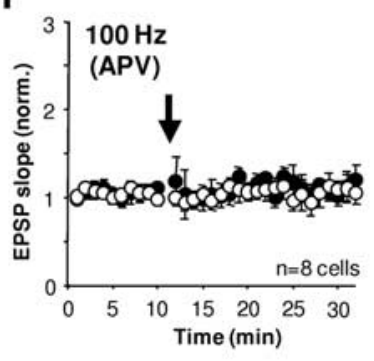

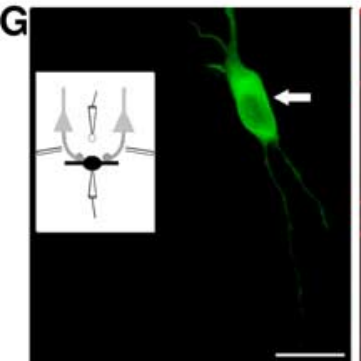
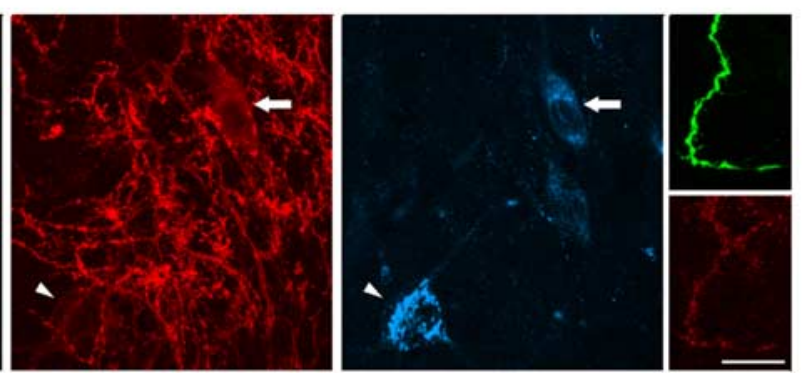

Figure 1. Long-term potentiation in 0-LM interneurons is induced at negative postsynaptic membrane potential. $\boldsymbol{A}$, Recording in perforated-patch mode showing that glutamatergic synapses onto an 0-LM cell do not exhibit NMDA receptor-dependent Hebbian LTP. The plot shows initials slopes of EPSPs in response to extracellular stimulation of two glutamatergic pathways (solid and open symbols) targeting the 0 -LM cell. After a baseline, $1 \mathrm{~Hz}$ stimulation (120 pulses) was delivered in one pathway (solid symbols) while postsynaptic membrane potential was simultaneously depolarized to $0 \mathrm{mV}$. This did not change EPSP slope. Twenty consecutive traces of EPSPs in both pathways before $(5 \mathrm{~min})$ and after $(25 \mathrm{~min})$ the pairing are shown above each plot. Pairing protocol is illustrated in an inset, and the timing is indicated by an arrow. $\boldsymbol{B}$, Mean \pm SEM of baseline-normalized EPSP in three 0 -LMs cells studied in perforated patch as in $\boldsymbol{A}$. The two pathways are superimposed; solid and open symbols indicate the paired and control pathways as in $\boldsymbol{A}$. Schematic shows the experimental design and positioning of extracellular stimulation electrodes. C, Robust LTP is induced in glutamatergic synapses onto 0-LM cells if high-frequency afferent stimulation occurs when the cell membrane potential is clamped at negative potentials. Recording is in perforated patch; the plot shows EPSP initial slopes in response to stimulation of two glutamatergic pathways (solid and open symbols) targeting an 0-LM cell. After baseline, HFS (100 Hz; timing indicated by an arrow) was delivered in one pathway (solid symbols) while membrane potential was voltage clamped to $-70 \mathrm{mV}$ during the train. This anti-Hebbian pairing induced a robust pathway-specific LTP of the EPSP. The open symbols indicate EPSPs in the control pathway. EPSPs in both pathways before ( $5 \mathrm{~min}$ ) and after ( $35 \mathrm{~min}$ ) the HFS are shown above. The scaling is as in $\boldsymbol{A}$. Stimulation protocol is illustrated in the inset. APV indicates continuous presence of NMDAR blocker DL-APV (100 $\mu \mathrm{M})$. D, Mean \pm SEM of baseline-normalized EPSP in 160-LMs cells studied in perforated patch as in C, postsynaptic membrane potential clamped to -70 to $-90 \mathrm{mV}$ during HFS. $P$ indicates significance between the two pathways (unpaired $t$ test). $\boldsymbol{E}$, Pairing $100 \mathrm{~Hz}$ afferent stimulation with depolarization to $0 \mathrm{mV}$ in perforated patch fails to elicit LTP in 0 -LM cells. The solid and open symbols represent tetanized and control pathways. Pairing protocol is illustrated in inset; arrow shows timing. APV indicates that NMDARs are blocked by $100 \mu \mathrm{m}$ DL-APV. Consecutive EPSPs in the two pathways during baseline ( $5 \mathrm{~min})$ and after the pairing (35 $\mathrm{min}$ ) are shown above. The scaling is as in $\boldsymbol{A}$. $\boldsymbol{F}$, Mean \pm SEM of EPSP slope in two pathways tested in eight 0-LM cells in perforated patch and plotted as in $\boldsymbol{B}$ and $\boldsymbol{D}$. G, Fluorescence micrographs showing immunoreactivity for mGluR1 $\alpha$ (middle; red) and somatostatin (middle; blue) in the soma of a recorded and biocytin (left; green) labeled 0-LM cell (arrow) shown in $\boldsymbol{E}$. An mGluR1 $\alpha$-immunopositive and biocytin-labeled distal dendrite is shown on the right (green, red). Note immunoreactivity in cells that were not recorded (arrowhead). Scale bars: left, middle panels, $20 \mu \mathrm{m}$; right panels, $10 \mu \mathrm{m}$.

recordings. Chemicals were purchased from Sigma-Aldrich, and drugs were purchased from Tocris Cookson or Ascent Scientific.

Data analysis and statistics

In the analysis of LTP experiments, the initial slope of the EPSPs (3-5 ms from onset) was measured to restrict analysis to monosynaptic excitatory inputs. The initial slope time window and EPSP onset were determined from the average of all baseline EPSPs. For coefficient of variation $(\mathrm{CV})$ analysis, EPSP initial slope values were taken from 5 min recording periods in the tetanized and control pathways. The mean and SD values (20 data points each) were used to estimate $\mathrm{CV}^{-2}$ for periods before $(-5-0$ $\min$ ) and 15-20 min after the high-frequency stimulation. The noise variance $\left(\operatorname{Var}_{\text {noise }}\right)$ was measured from 3 to $5 \mathrm{~ms}$ time window preceding the stimulation and subtracted from the EPSP slope variance ( $\operatorname{Var}_{\text {EPSP }}$ ) before calculation of $\mathrm{CV}^{-2}$, using the following formula: mean $\mathrm{EPSP}^{2} /\left(\operatorname{Var}_{\mathrm{EPSP}}-\mathrm{Var}_{\text {noise }}\right)$, where mean EPSP is the mean EPSP slope (Min et al., 1998).

In whole-cell current-voltage $(I-V)$ recordings, the EPSC rectification index was obtained by dividing the amplitude of the EPSC recorded at $+60 \mathrm{mV}$ by that measured at $-60 \mathrm{mV}$. To analyze the AMPAR- and kainate receptormediated components of stimulus-evoked synaptic transmission, the peak EPSC amplitude in control conditions was quantified as the difference between a $10 \mathrm{~ms}$ baseline before stimulation and the mean value in a 1-3 ms window around the peak of the average monosynaptic response. The slope and decay time constants were evaluated for individual events. The EPSC decay time constant was evaluated by fitting a monoexponential function. To estimate the charge transfer of evoked EPSCs, the rising slope and decay time constant were evaluated for the single pulse-evoked EPSC (control) and the EPSC after the fifth pulse in [1-(4aminophenyl)-4-methyl-7,8-methylenedioxy5H-2,3-benzodiazepine (GYKI53655)]. These experimentally derived kinetic variables were used to simulate EPSC waveforms made up of a linear rise and monoexponential decay. Waveforms were scaled by the amplitude of the EPSC after the single or fifth pulse in control and GYKI conditions, respectively. Charge transfer was estimated by integrating these waveforms and the ratio of the two integrals evaluated. Hence, this ratio compared the summated, GYKI-insensitive EPSC to a single pulseevoked EPSC in control conditions, and would thus be an overestimation and an upper limit of the contribution of the GYKI-insensitive component.

Mini-analysis was done in Igor Pro, version 6.01 , using a modified version of the minifit procedure (Hwang and Copenhagen, 1999). The procedure detects events based on the first and second derivatives and a user-specified amplitude detection threshold. See supplemental Figures 3 and 4, and supplemental Table 1 (available at www.jneurosci.org as supplemental material).

Data are shown as mean \pm SEM. Data were 
baseline-normalized within each pathway, using a 10 min baseline, and analyzed with Student's paired $t$ test. Within each cell, the change in slope in the paired pathway was compared with that of the control pathway with an unpaired $t$ test.

\section{Anatomical analysis}

Neurons were filled with Neurobiotin (Vector Labs) or biocytin (Sigma-Aldrich) during whole-cell recordings (at least $30 \mathrm{~min}$ ). Slices were fixed overnight at $4^{\circ} \mathrm{C}$ in a solution containing $4 \%$ paraformaldehyde, $0.05 \%$ glutaraldehyde, and $\sim 0.2 \%$ picric acid in $0.1 \mathrm{M}$ sodium phosphate buffer (PB) (BDH). During fixation, slices were kept between two cellulose nitrate membrane filter papers (Whatman) to minimize deformation. The next day, slices were washed thoroughly in $0.1 \mathrm{M}$ phosphate buffer and stored in $\mathrm{PB}$ plus $0.05 \%$ sodium azide $(\mathrm{BDH})$ at $4^{\circ} \mathrm{C}$. For resectioning, slices were embedded and fixed in $20 \%$ gelatin and resectioned at $70 \mu \mathrm{m}$ thickness using a vibrating microtome (Leica VT1000S; Leica Microsystems). The sections were washed once in $0.1 \mathrm{M} \mathrm{PB}$, and several times in $50 \mathrm{~mm}$ Tris-buffered saline (TBS) (Sigma-Aldrich) with $0.3 \%$ Triton $\mathrm{X}-100$, and then incubated for at least $5 \mathrm{~h}$ with Alexa Fluor 488-labeled streptavidin (Invitrogen; diluted 1:1000) in TBS with $0.3 \%$ Triton $\mathrm{X}-100$. Sections were mounted in Vectashield (Vector Laboratories) under coverslips and examined with a fluorescent microscope. Images were captured using a CCD camera (C4747-95; Hamamatsu Photonics) with an appropriate filter set (Ferraguti et al., 2005) (see supplemental Methods, available at www.jneurosci.org as supplemental material) and analyzed using the Openlab 4.0.4 image analysis software package (Improvision).

O-LM cells were identified on the basis of the main axon ascending from s. oriens, with an axonal arborization mostly in s. lacunosum moleculare $(n=83)$, or metabotropic glutamate receptor subtype $1 \alpha$ (mGluR $1 \alpha)$ immunoreactivity in the somatodendritic plasma membrane and characteristic somatostatin immunoreactivity in the soma (Baude et al., 1993; BlascoIbáñez and Freund, 1995; Maccaferri and McBain, 1995; Sik et al., 1995; Ali and Thomson, 1998). Some cells provided additional minor innervations to other layers. O-LM cells had a horizontal dendritic arborization bearing many filopodial spines and appendages in s. oriens and the alveus (McBain et al., 1994). For immunofluorescence experiments, sections were processed as described previously (Jinno et al., 2007) (see supplemental Methods, available at www.jneurosci.org as supplemental material). On completion of immunoreactions, sections were processed for visualization of Neurobiotin as described previously (Losonczy et al., 2002). For illustration, selected cells were reconstructed from several 70 $\mu \mathrm{m}$ sections using a drawing tube.

\section{Results}

Consistent anti-Hebbian LTP properties in hippocampal CA1 O-LM cells

We patched horizontal cells in s. oriens of the CA1 area under infrared DIC microscopy. In plasticity studies, cells were first recorded in the perforated-patch mode and then repatched in whole-cell voltage clamp using a new pipette. This repatching method allowed us to study synaptic plasticity with minimal disturbance of the cytosol, with subsequent whole-cell access to test
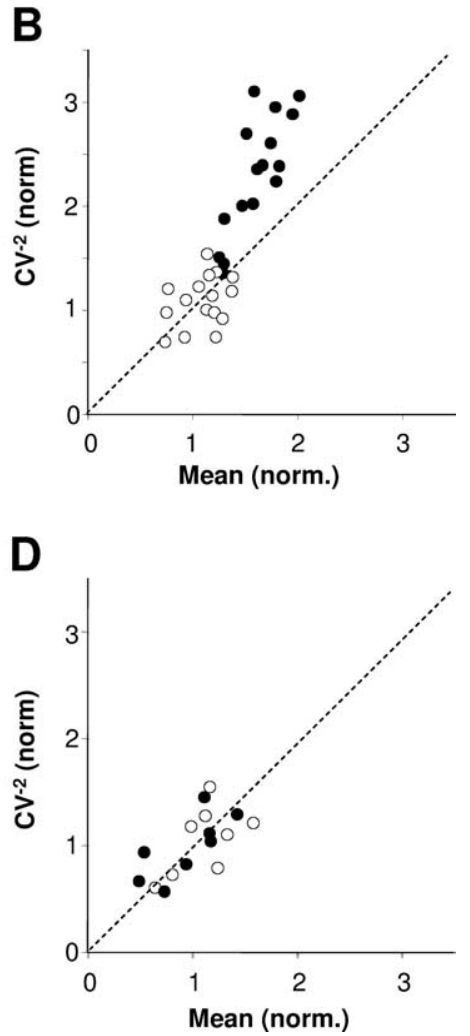

Figure 2. Expression of anti-Hebbian LTP in 0-LM cells shows systematic pathway specificity and consistent changes in the EPSP coefficient of variance. $A$, EPSP slopes in 0 -LM cells tested for anti-Hebbian LTP induction. Average of baseline-normalized EPSP slopes in tetanized and control pathway plotted against each other in all 16 cells studied and shown in Figure 1D. The data points represent averages of EPSPs at 15-20 min after the high-frequency afferent stimulation. Three cells closest to the line of EP initial slopes plotted against the mean in the pathways. Values are from EPSPs at 15-20 min after the high-frequency pathway (solid symbols) are accompanied by a systematic increase in $\mathrm{CV}^{-2}$ whereas EPSPs that did not potentiate are not The control pathway is illustrated by open symbols. C, EPSP slopes with no LTP in 0-LM cells in which high-frequency afferent eight cells shown in Figure 1F. D, CV ${ }^{-2}$ plotted against the mean in the two pathways as in $\boldsymbol{B}$. In the absence of LTP, there is no difference in the distribution of the data points representing the pathways.

synaptic currents in voltage clamp and fill cells with biocytin for post hoc anatomical identification (supplemental Fig. 1, available at www.jneurosci.org as supplemental material). Of 212 cells recorded and subsequently processed histologically, 83 cells were identified as O-LM interneurons (supplemental Table 2, available at www.jneurosci.org as supplemental material). The data reported here focus exclusively on the 83 identified cells.

We first asked whether Hebbian NMDA receptor-dependent LTP could be evoked in identified O-LM cells. NMDARdependent LTP can be induced in a subpopulation of unidentified nonpyramidal cells in the CA1 area, mainly in s. radiatum by pairing low-frequency $(1-2 \mathrm{~Hz})$ stimulation of presynaptic afferents with postsynaptic depolarization. A small population of interneurons in s. pyramidale and s. oriens also show NMDARdependent LTP (Wang and Kelly, 2001; Lamsa et al., 2005, 2007a), and we therefore asked whether O-LM cells could belong to this group. EPSPs were elicited with two extracellular stimulation electrodes positioned in s. oriens. $\mathrm{GABA}_{\mathrm{A}}$ and $\mathrm{GABA}_{\mathrm{B}}$ receptors were blocked with picrotoxin $(100 \mu \mathrm{M})$ and CGP55845 (1 $\mu \mathrm{M})$, respectively. Analyses were focused on the EPSP initial slope to avoid contamination of the monosynaptic response by polysynaptic activity (Maccaferri and McBain, 1996; Lamsa et al., 2005; Glickfeld and Scanziani, 2006). After recording a stable 

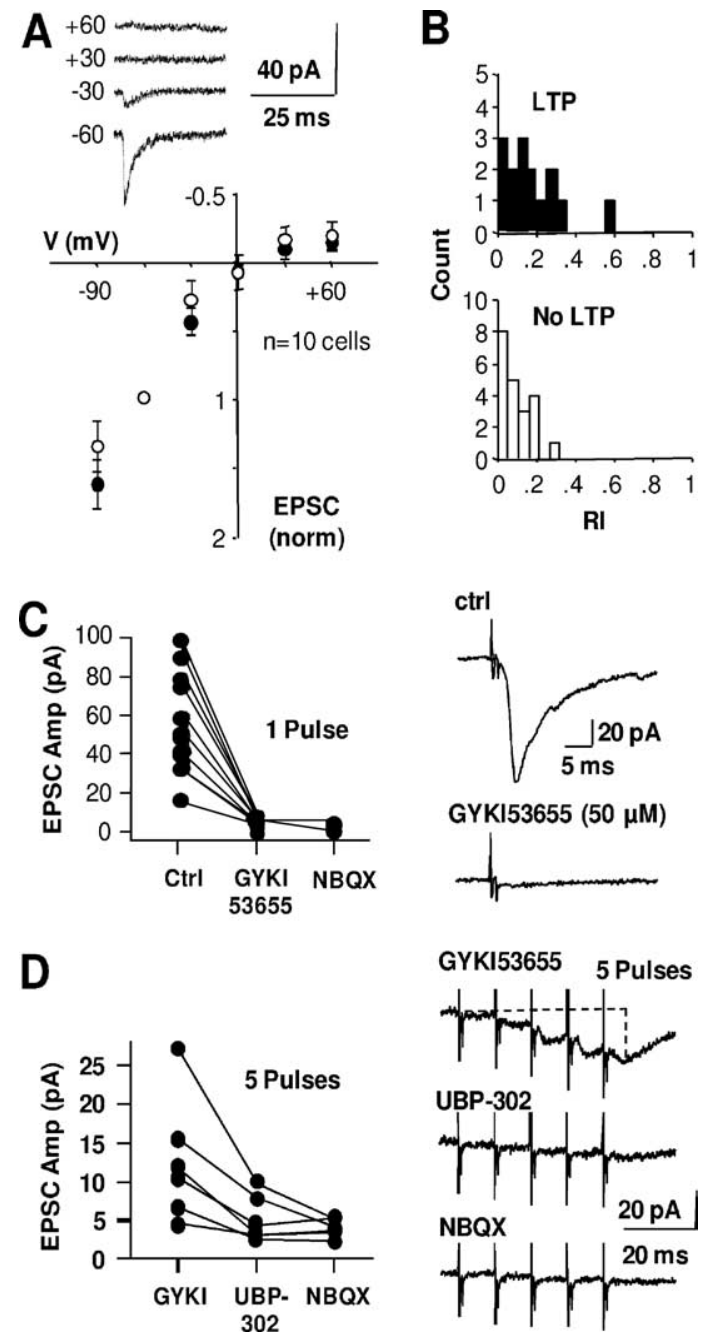

Figure 3. Fast glutamatergic input to 0 -LM interneurons is mediated mainly via $C P$ AMPARs, but kainate receptors are activated during high-frequency stimulation. $A$, Whole-cell voltage-clamp recordings of 0-LM cells, after LTP protocol in perforated patch, reveal strongly inward rectifying EPSCs in both tetanized and control pathway (data taken 20-60 min from HFS). Top, EPSCs traces (average of 5) in one cell evoked at different holding potentials. Bottom, Normalized $I-V$ relationship of the EPSCs reveals no differences in the rectification in synapses with LTP (solid symbols) and in control pathway (open symbols). I values were normalized by EPSC mean at $-60 \mathrm{mV}$ in each cell. Data are from 100 -LM cells that showed LTP with good access resistance. $\boldsymbol{B}$, Histogram shows distribution of rectification indices in the synapses with LTP (solid) and no LTP (open) in all repatched cells in this study. RI indicates EPSC rectification index. In addition to the 10 cells shown in $A$, the data include two 0 -LM cells in which LTP was not induced and six cells tested for different drugs later in this study. C, Separate study in 0-LM cells in whole-cell voltage clamp shows that EPSCs evoked by single shock stimulation were blocked by GYKI53655, a selective antagonist for AMPA receptors. Additional application of 50 $\mu \mathrm{M}$ NBQX did not further inhibit the residual inward current. Right, An averaged trace of five EPSCs in one 0-LM cell before and after application of GYKI53655. D. High-frequency stimulation of the synapses ( 5 pulses at $100 \mathrm{~Hz}$ ) in the presence of GYKI53655 (50 $\mu \mathrm{m}$ ) elicited EPSCs sensitive to selective kainate receptor antagonist. The plot shows amplitude of the train-evoked response (amplitude of fifth pulse of the train) in six 0-LM cells. The GYKI-insensitive EPSC was strongly inhibited by UBP-302 $(25 \mu \mathrm{M})$, a selective antagonist for GluR5-containing kainate receptors. Subsequent application of NBQX ( $50 \mu \mathrm{M})$ did not significantly suppress inward current amplitude any further. Right, Traces (averages of 5-7) from one 0-LM cell showing GYKIinsensitive EPSCs elicited by the train, inhibition by UBP-302, and the effect of subsequent application of NBQX (50 $\mu \mathrm{M})$. The dotted line shows EPSC amplitude for the fifth pulse.

baseline in current-clamp mode, the amplifier was switched to voltage-clamp mode and stimulation of one pathway at $1 \mathrm{~Hz}(120$ pulses) was paired with brief $(300 \mathrm{~ms})$ depolarization of the $\mathrm{O}-\mathrm{LM}$ cell to $0 \mathrm{mV}$ (somatic potential corrected for series resis- tance errors) (see Materials and Methods). Stimulation of the other pathway was interrupted during pairing to be used as a control. EPSPs were followed in both pathways for $20 \mathrm{~min}$ after the pairing. The pairing caused no change in EPSP slope in any of the identified O-LM cells studied (Fig. 1A,B). Unlike pyramidal cells and several interneurons in s. radiatum (Lamsa et al., 2005, 2007a), O-LM interneurons did not exhibit NMDA receptordependent LTP.

Many interneurons in the CA1 area show NMDARindependent LTP, which is induced by high-frequency stimulation (HFS) of glutamatergic afferents (Perez et al., 2001; Lamsa et al., 2007a). Hence, in the next set of experiments, afferents were stimulated at a high frequency. NMDARs were systematically blocked with DL-APV $(100 \mu \mathrm{M})$ in these and all subsequent experiments to prevent contamination of EPSPs by passive propagation of LTP occurring on pyramidal cells (Maccaferri and McBain, 1996). After a stable baseline, $100 \mathrm{~Hz}$ stimulation (1 s; delivered twice with a $20 \mathrm{~s}$ interval) was delivered to one pathway while the postsynaptic cell was voltage clamped negative to the resting membrane potential (somatic potential, -70 to -90 $\mathrm{mV})$. EPSPs were recorded for at least $20 \mathrm{~min}$ after the HFS, repatched, and identified as above. HFS paired with hyperpolarization resulted in LTP that lasted for the duration of the experiment (at least 20 min after the HFS) in 13 of 16 O-LM cells tested. We set the criteria for LTP as a pathway-specific and significant $(p<0.05, t$ test) increase in EPSP slope to at least $125 \%$ of baseline. In the remaining three cells, the potentiation either did not meet the criterion for LTP or was not restricted to the tetanized pathway. The averaged baseline-normalized EPSP initial slope in the tetanized pathway, including all 16 O-LM cells, was $152 \pm 6 \%$, whereas the EPSP in the control pathway was $96 \pm 7 \%$ (15-20 min after HFS) (Fig. 1C,D). In five of the cells, LTP was followed at least for $30 \mathrm{~min}$. EPSP potentiation remained stable and was $149 \pm 15 \%$ at $15-20 \mathrm{~min}$ and $165 \pm 13 \%$ at $25-30 \mathrm{~min}$ after HFS $(p=0.74)$.

In another sample of O-LM cells, we paired HFS with postsynaptic depolarization to $0 \mathrm{mV}$ (somatic potential). This failed to generate LTP $(n=8)$ (Fig. $1 E, F)$. Fifteen to $20 \mathrm{~min}$ after the HFS, the baseline normalized EPSP slopes in the two pathways were $109 \pm 7$ and $103 \pm 6 \%$, respectively. Identified O-LM cells (Fig. $1 G)$ thus exhibit robust anti-Hebbian LTP.

In some interneurons of s. oriens, LTP has previously been reported to have a presynaptic locus of expression (Lapointe et al., 2004; Lamsa et al., 2007a; Le Vasseur et al., 2008). We asked whether this holds for anti-Hebbian LTP in identified O-LM cells by analyzing the CV of the EPSP initial slopes in the two pathways in the abovementioned experiments. LTP was associated with an increase in $\mathrm{CV}^{-2}$ relative to the mean. The increase was positively correlated with the degree of potentiation of the EPSP in the tetanized pathway (Fig. $2 \mathrm{~A}, \mathrm{~B}$ ). A larger increase in $\mathrm{CV}^{-2}$ relative to the mean is consistent with an increase in transmitter release probability as a potentiation mechanism in the synapses (rather than an increased number of postsynaptic AMPA/kainate receptors or unsilencing of synapses) (Edwards et al., 1990; Clements and Silver, 2000). $\mathrm{CV}^{-2}$ did not change in the control pathway. Neither the tetanized nor the control pathway showed a change in $\mathrm{CV}^{-2}$ after pairing with depolarization (Fig. 2C,D).

\section{Fast glutamatergic excitation of O-LM interneurons at} negative membrane potential is mediated via CP-AMPA and kainate receptors

Repatching the cells in whole-cell mode allowed us to study EPSCs underlying the EPSPs in O-LM cells. In 12 of 16 cells tested 
Table 1. EPSC kinetics in control (single shock) and in $50 \mu \mathrm{M}$ GYKI53655 (fifth shock)

\begin{tabular}{|c|c|c|c|c|c|}
\hline & $\begin{array}{l}\text { Amplitude } \\
(\mathrm{pA})\end{array}$ & $10-90 \%$ Rise time (ms) & $\begin{array}{l}\text { Slope (pA/ } \\
\text { ms) }\end{array}$ & Decay time constant (ms) & Area $(\mathrm{nC})$ \\
\hline Control & $79.7 \pm 6.7$ & $0.8 \pm 0.1$ & $58.4 \pm 4.6$ & $4.1 \pm 0.2$ & $385.8 \pm 63.9$ \\
\hline GYKI53655 & $6.5 \pm 1.0$ & $1.7 \pm 0.3$ & $1.8 \pm 0.3$ & $8.9 \pm 1.0$ & $70.1 \pm 13.0$ \\
\hline
\end{tabular}

Means \pm SEM are presented for four cells in which monosynaptic EPSCs could be distinguished. EPSC amplitude was measured from baseline preceding the first/fifth shock in control and GYKI53655, respectively. Data were used to estimate charge transfer.

for anti-Hebbian LTP and repatched, whole-cell access resistance was suitable for voltage-clamp recordings and $I-V$ analysis. EPSCs were systematically highly inward rectifying in all O-LM cells exhibiting anti-Hebbian LTP (Fig. 3A). In addition, the rectification index (RI) (detected 20-60 min after the HFS) did not differ significantly between potentiated $(0.14 \pm 0.07)$ and control pathways $(0.04 \pm 0.05 ; p=0.15 ; n=10$ cells; $t$ test $)$. In two of the three cells that failed to reach the LTP criterion, the EPSC $I-V$ relationship was successfully measured: EPSCs were similarly inward rectifying in both pathways (RI mean, 0.13 and 0.10 , respectively). EPSC rectification indices taken from 25 O-LM cells in this study showed that there is little variation among the cells (Fig. 3B). We thus conclude that O-LM cells consistently exhibit highly rectifying EPSCs, characteristic of $\mathrm{Ca}^{2+}$-permeable AMPA receptors (Angulo et al., 1997). The influx of $\mathrm{Ca}^{2+}$ via such receptors may explain anti-Hebbian LTP induction. The similarity of RI between LTP and control pathways implies that LTP is not accompanied by a change in the proportion of rectifying receptors at the potentiated synapses.

Because the rectification analysis focused on the peak of the EPSCs, which is dominated by fast AMPA receptors, it says little about whether kainate receptors are involved in the $\mathrm{Ca}^{2+}$ influx during anti-Hebbian pairing. We therefore estimated the contribution of kainate receptors to glutamatergic synapses onto identified O-LM interneurons. We recorded from horizontal cells in the whole-cell voltage-clamp configuration, and examined the effect of selective blockade of AMPA receptors with GYKI53655 $(50 \mu \mathrm{M})$. The amplitude of single stimulus-evoked EPSCs (57 \pm 7 pA) was strongly attenuated by GYKI53655 in every O-LM cell studied, leaving only $7 \pm 1 \%$ residual amplitude $(n=11)$ (Fig. $3 C)$. To examine the kinetics and pharmacological properties of the residual EPSC, we delivered trains of stimuli at $100 \mathrm{~Hz}$ (five pulses) in the continued presence of GYKI53655. This revealed an EPSC that exhibited substantial summation: the ratio of the peak currents after the fifth and first stimuli was $4.2 \pm 0.5(n=4$ cells). The summated GYKI-insensitive EPSCs were characterized by slower kinetics than those of the GYKI-sensitive currents $(p<0.05 ; n=4)$ (Table 1$)$. The decay time constants of EPSCs in control conditions and in the presence of GYKI were $4.1 \pm 0.2$ and $8.9 \pm 1.0 \mathrm{~ms}$, respectively. The estimated charge transfer carried by the summated, residual EPSC induced by the fifth pulse was only $19 \pm 3 \%$ of the charge transfer for a single EPSC in control conditions (see Materials and Methods). The train-evoked, GYKI53655-resistant EPSCs were strongly inhibited by the GluR5 subunit-selective kainate receptor antagonist (S)-1-(2-amino-2carboxyethyl)-3-(2-carboxybenzyl)pyrimidine-2,4-dione (UBP302) $(25 \mu \mathrm{M})$ (Fig. 3D). In six cells tested, the amplitude after the fifth pulse $(12 \pm 3 \mathrm{pA})$ was inhibited to $44 \pm 5 \%$ by UBP-302. Additional application of a high concentration of NBQX $(50 \mu \mathrm{M})$, which blocks both AMPA and kainate receptors, did not significantly reduce the inward current any further $(p=0.15)$. We therefore conclude, first, that kainate receptors make only a relatively small contribution to EPSCs in rat O-LM cells and, second, that they are principally GluR5-containing.
We applied a second approach to look at the contribution of AMPA and kainate receptors to synaptic transmission in O-LM cells. The relative contributions of AMPA and kainate receptors should be reflected in the kinetics and pharmacological properties of mEPSCs recorded in the presence of TTX $(1 \mu \mathrm{M})$ (GABA and glutamate NMDARs were blocked as above). Cells were initially held at $-60 \mathrm{mV}$. This revealed a population of spontaneous inward currents with fast rise time and variable decay time constants ( $n=14$ cells) (Fig. $4 A$; supplemental Fig. 5 , available at www.jneurosci.org as supplemental material).

Given the wide distribution of mEPSC kinetics in the cells, we asked whether fast- and slow-decaying events show different sensitivities to membrane potential by clamping the cell at depolarized potentials $(+40$ to $+50 \mathrm{mV}$ ). The frequency of detected events decreased to $9 \pm 3 \%$ of the frequency at $-60 \mathrm{mV}(p<$ $0.05 ; n=4$; paired $t$ test) (Fig. $4 B$ ). This was accompanied by a nonsignificant reduction in the mean amplitude of detected events $(p=0.13)$. The decrease in frequency and amplitude of detected events is consistent with the hypothesis that most events fall below detection threshold on depolarization, most simply explained by rectification of the receptors mediating the EPSCs. Indeed, the maximal event amplitude decreased from $50.8 \pm 1.5$ $\mathrm{pA}$ at $-60 \mathrm{mV}(n=4)$ to $11.2 \pm 1.2 \mathrm{pA}$ at +40 to $+50 \mathrm{mV}$. mEPSCs at positive voltages were detected too infrequently to obtain reliable estimates of the distribution of decay time constants.

Overall, the analysis of mEPSCs is in line with the outcome of stimulus-evoked EPSCs, and indicates that highly rectifying glutamate receptors mediate the majority of EPSCs in O-LM cells. We next studied the effect of selective AMPAR antagonists on mEPSCs, to determine whether a subpopulation of kainate receptor-mediated events could be detected. After baseline recording of mEPSCs (6 min), slices were exposed either to GYKI53655 $(50 \mu \mathrm{M})$ or to a low concentration of NBQX $(1 \mu \mathrm{M})$, which has been shown to act as a relatively selective blocker of AMPA receptors (Bureau et al., 1999). All detected mEPSCs were blocked with GYKI53655 ( $n=5$ cells), and in separate experiments a similar result was obtained with $1 \mu \mathrm{M}$ NBQX $(n=5$ cells). This argues that the overwhelming majority of mEPSCs were mediated by AMPA rather than kainate receptors (Fig. 4C) (Wilding and Huettner, 1995; Cossart et al., 2002; Goldin et al., 2007). Because a population of mEPSCs resistant to $50 \mu \mathrm{M}$ GYKI53655 or $1 \mu \mathrm{M}$ NBQX could not be detected, we conclude that the variable mEPSC decay time constants in O-LM cells (Fig. $4 A$ ) result mainly from differential electrotonic filtering (Williams and Mitchell, 2008) of mainly AMPA receptor-mediated mEPSCs arising at diverse locations in the dendritic arborization (McBain and Dingledine, 1993).

\section{AMPA but not kainate receptors are required for anti- Hebbian LTP induction}

Although fast glutamatergic excitation of O-LM cells is mediated for the most part by inward-rectifying AMPARs, this does not exclude a disproportionate role for kainate receptors, which can 
A
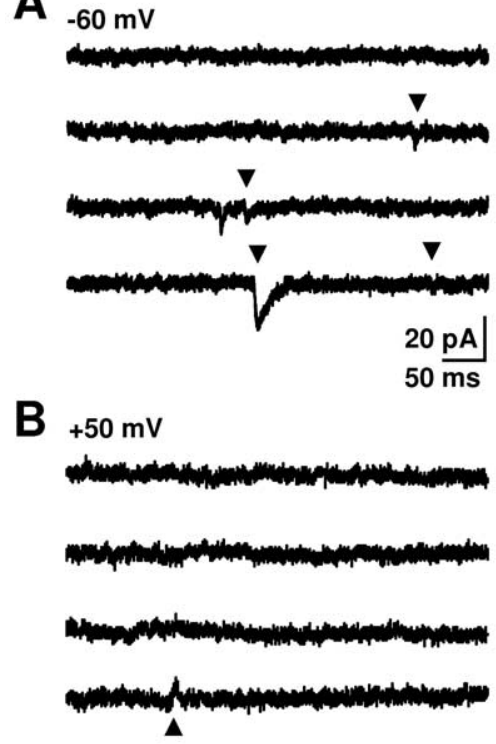

C

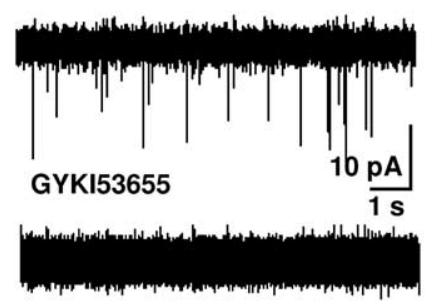

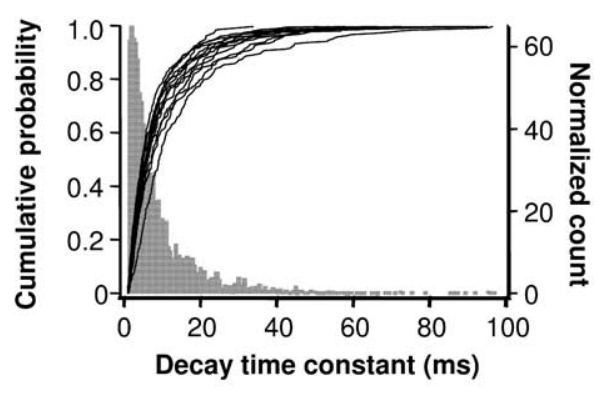
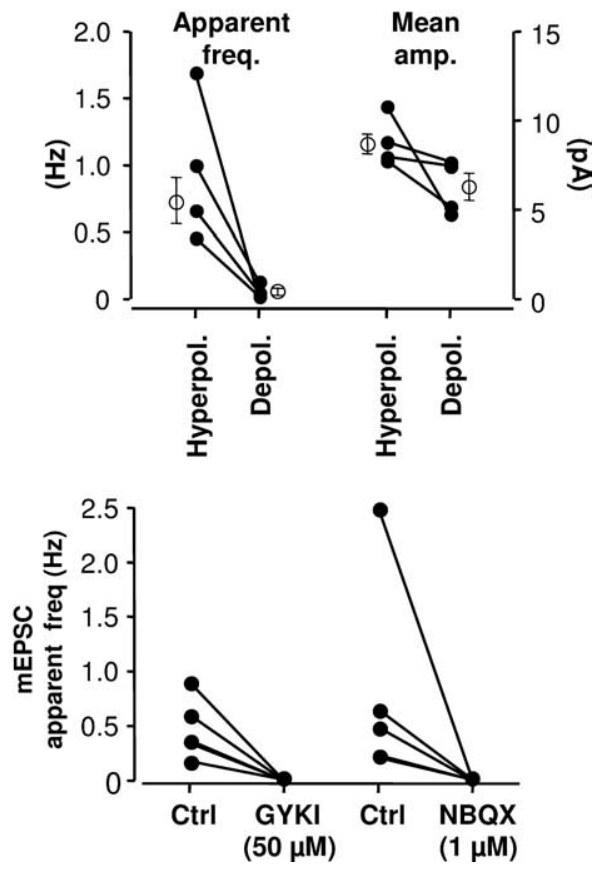

Figure 4. Miniature EPSCs in 0 -LM interneurons are mediated by rectifying AMPA receptors. $A, m E P S C s$ show extensive kinetic variability in 0 -LM cells. Left, Inward mEPSCs in an 0-LM cell voltage clamped at $-60 \mathrm{mV}$ in the presence of TTX (1 $\mu \mathrm{M})$. GABA and glutamate NMDA receptors were blocked throughout. Two seconds of continuous recording are shown in traces. Detected $\mathrm{mEPSCs}$ are indicated by an arrowhead. Right, Cumulative probabilities of decay time constants of mEPSCs for 14 0-LM cells and average normalized histogram showing kinetic distribution of mEPSC decay time constants in the 0 -LM cells. Histogram was normalized by detected event number in each cell. $\boldsymbol{B}, \mathrm{mEPSC}$ frequency is dramatically decreased at depolarized membrane potential. Left, Reversed polarity of mEPSCs in the same cell as above held at $+50 \mathrm{mV}$. An arrowhead indicates a mEPSC. Right, The plot shows $\mathrm{mEPSC}$ frequency and amplitude at hyperpolarized (at $-60 \mathrm{mV}$ ) and depolarized (at +40 to $+50 \mathrm{mV}$ ) potentials. Shown are data points of individual cells recorded at negative and positive potentials connected with line. Mean \pm SEM for the values in each condition are shown as open symbols. C, mEPSCs in 0-LM cells are blocked by selective AMPA receptor antagonists. Left, Recording of $\mathrm{mEPSC}$ at $-60 \mathrm{mV}$ before and after application of selective AMPA receptor blocker, GYKI53655 (50 $\mu \mathrm{m})$. Right, Plot shows mEPSC frequency in individual cells in control conditions and in the presence of selective AMPAR antagonists GYKI53655 or NBQX (1 $\mu \mathrm{M})$.

also be calcium-permeable, in LTP induction. Indeed, their relatively slower kinetics is suited to temporal summation, and their contribution to synaptic transmission is revealed by highfrequency stimulation, similar to that used in the anti-Hebbian LTP induction protocol. Therefore, we next attempted to dissect the relative contributions of AMPA and kainate receptors in antiHebbian LTP induction.

Because the small size of the kainate receptor-mediated EPSC precluded reliable measurement of the rectification index, and associated calcium permeability (Egebjerg and Heinemann, 1993; Köhler et al., 1993; Bowie and Mayer, 1995; Kamboj et al., 1995; Rogawski et al., 2003), we used selective kainate and AMPA receptor antagonists to address the question. We first tested the effect of the relatively selective AMPA receptor blocker, $1 \mu \mathrm{M}$ NBQX, on LTP induction using sequential perforated-patchwhole-cell recording as described above. We recorded EPSPs in two pathways and after a baseline NBQX was washed in. This strongly inhibited the EPSP initial slope to $13 \pm 2 \%$ of baseline in both pathways within $7 \mathrm{~min}(n=4$ cells; both pathways). High-frequency stimulation was then delivered to one pathway while the somatic membrane potential was clamped at -70 to $-90 \mathrm{mV}$. Washout of NBQX was started immediately after the HFS, and recovery of the EPSPs was followed in both pathways for at least $25 \mathrm{~min}$. Initial slopes in the tetanized and control pathways recovered to $38 \pm 9$ and $43 \pm$ $11 \%$ of the baseline, respectively, in 20-25 $\min (p=0.43 ; n=4)$ (Fig. $5 A, B)$. Thus, selective blockade of AMPA receptors was sufficient to prevent the induction of antiHebbian LTP.

We next studied the effects of the GluR5 blocker UBP-302 in separate slices. Slices were exposed to UBP for at least 20 min before an experiment so that EPSPs were stable before the start of baseline recording. HFS in the presence of UBP resulted in LTP in five of six tested O-LM cells. The baseline-normalized initial slope was potentiated to $155 \pm 13 \%, 15-20 \mathrm{~min}$ after the HFS (all six cells included). The EPSP in the control pathway was $103 \pm$ $11 \%$ of baseline $(p<0.01)$. Thus, in contrast to the effect of blocking AMPA receptors, UBP-302 did not prevent antiHebbian LTP induction.

We next tested the effect of GYKI53655, another AMPAR antagonist, using the same experimental design. A lower concentration $(25 \mu \mathrm{M})$ than in the previous experiments (Fig. 3C) was used to facilitate washout of the drug. Bath application of GYKI reduced the initial slope to $9 \pm 2 \%$ of baseline within $8 \mathrm{~min}(n=22$ pathways in all 11 O-LM cells tested). High-frequency stimulation paired with hyperpolarization fully blocked LTP. Surprisingly, however, the EPSP recovered less in the tetanized pathway (67 $\pm 5 \%$ ) than in the control pathway $(81 \pm 3 \%)$ during GYKI washout ( $n=5$; $p<0.05$; paired $t$ test) (Fig. $6 A, B$ ). To determine whether this unexpected difference was a result of the specific induction protocol tested, we repeated the experiments with a Hebbian pairing. HFS was delivered in the presence of GYKI53655 together with depolarization to $0 \mathrm{mV}$. After washout, a qualitatively similar but statistically insignificant $(p=$ 0.12 ) trend was seen for the tetanized pathway to recover less than the control pathway ( $41 \pm 5$ and $56 \pm 4 \%$, respectively, $25 \mathrm{~min}$ after HFS; $n=6$ ) (Fig. $6 C, D$ ). These results suggest that a small LTD can be elicited in the tetanized pathway, uncovered by blocking AMPA receptors, although the size of the phenomenon precludes easy identification of the underlying mechanisms.

\section{Discussion}

We have dissected the roles of CP-AMPA and kainate receptors in the induction of anti-Hebbian LTP at excitatory synapses onto 
CA1 O-LM interneurons. Although synaptic currents are mediated by both AMPA and kainate receptors, CP-AMPAR but not kainate receptors are necessary for LTP induction. Moreover, by exploring different induction protocols, we conclude that long-term plasticity properties are strikingly homogeneous in this population of hippocampal interneurons.

\section{LTP induction via CP-AMPARs}

Unlike some other hippocampal interneurons (Ouardouz and Lacaille, 1995; Christie et al., 2000; Lamsa et al., 2005, 2007b), O-LM cells in the CA1 area do not exhibit NMDAR-dependent LTP. Rather, experiments with selective AMPAR blockers showed that CP-AMPARs are critical for LTP induction. Glutamate release by high-frequency tetanic stimulation was not sufficient to induce LTP when AMPARs were blocked. Given the pharmacological dependence of LTP on AMPARs and the fact that CP-AMPARs are highly inward rectifying, it was not surprising that LTP induction showed a strict dependence on the postsynaptic membrane potential. In line with the data presented here, we have previously shown that blockade of inward-rectifying AMPA/kainate receptors with polyamines at an intracellular site prevents LTP in several interneurons in s. oriens including O-LM cells (Lamsa et al., 2007a). Our results strongly suggest that $\mathrm{Ca}^{2+}$ influx via CP-AMPARs is necessary to trigger LTP (Lapointe et al., 2004; Lamsa et al., 2007a). Indeed, CPAMPARs provide spatially restricted calcium signaling in interneuron dendrites, which is a prerequisite for pathway specificity of LTP (Goldberg et al., 2003a,b; Kaiser et al., 2004; Rózsa et al., 2008).

We cannot rule out the possibility that LTP is accompanied by changes in AMPA receptor subunit composition, as has been reported in other cell types (Liu and CullCandy, 2000; Bellone and Lüscher, 2005; Plant et al., 2006; Liu and Zukin, 2007). However, we found no evidence that such a switch accompanied anti-Hebbian LTP, because the rectification ratios were similar in the conditioned and control pathways. After potentiation, calcium permeability of AMPARs is presumably preserved in these synapses. Analysis of changes in $\mathrm{CV}$ supports the notion that LTP at these synapses is presynaptically expressed.

mGluRs contribute to LTP induction in CA1 O-LM cells (Perez et al., 2001). Antagonists of mGluR1 or genetic lesion of the receptor prevent LTP in horizontal cells when the whole-cell recording method is used (Lapointe et al., 2004). However, the fact that tetanic stimulation in the presence
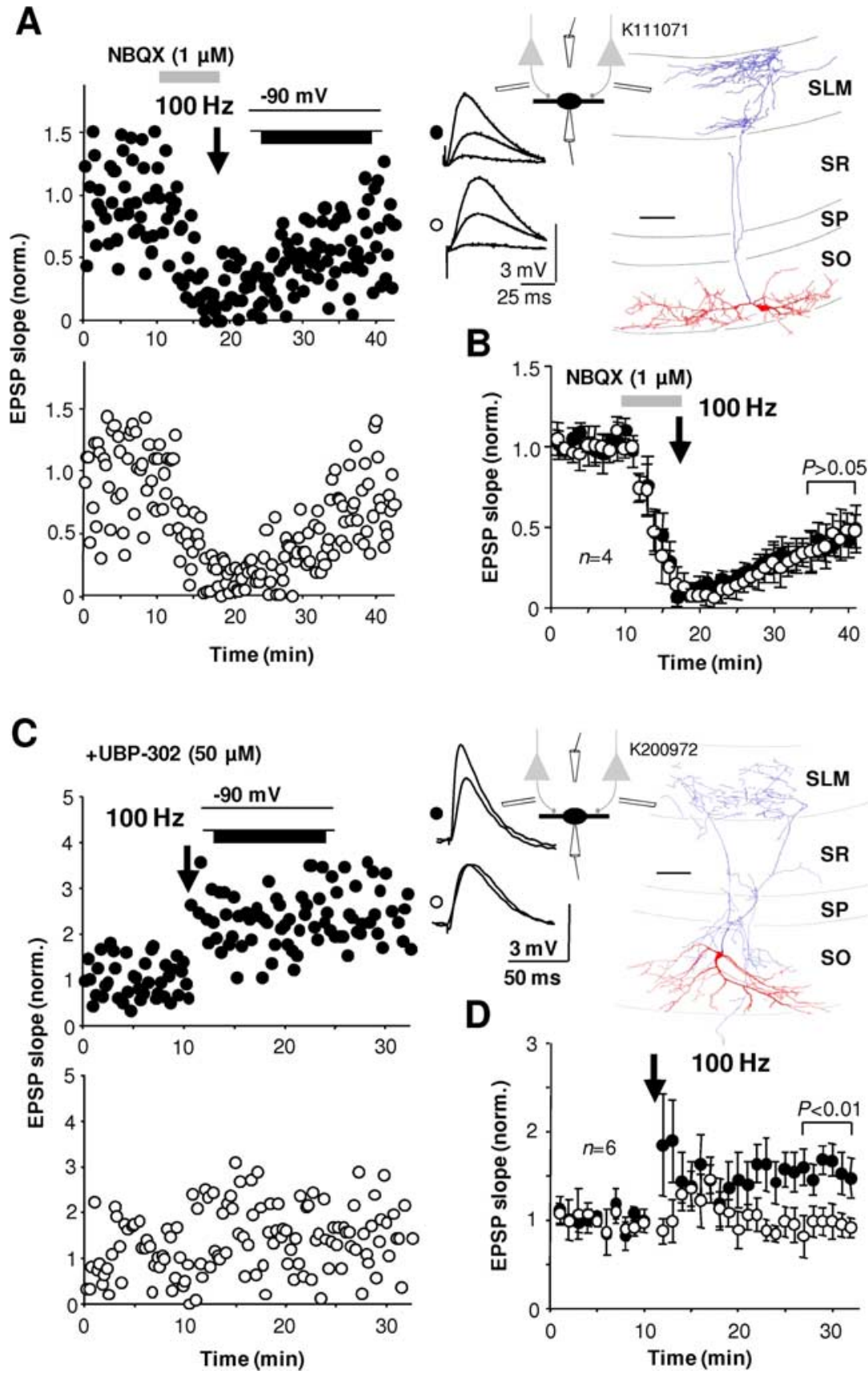

Figure 5. LTP in 0-LM interneurons requires AMPA but not kainate receptors. $A$, Inhibition of AMPAR with low concentration of NBQX $(1 \mu \mathrm{M})$ before HFS prevented LTP. EPSP slope was plotted in two pathways as in Figure $1 A$. After a baseline period, NBQX was washed in, and high-frequency stimulation was delivered to one pathway (solid symbols). Washout of NBQX started immediately after HFS. Recovery of the EPSPs during washout was similar in the tetanized and the control pathway, indicating that no LTP was induced. Application of NBQX is shown by horizontal bar, and timing of HFS is shown by an arrow. Right, Averaged EPSPS (20 events) in the two pathways during baseline, immediately after HFS, and after 20-25 min washout of NBQX. Shown is reconstruction of the 0 -LM cell labeled after repatching (indicated by schematic). Scale bar, $100 \mu \mathrm{m}$. B, Normalized mean \pm SEM of four similar experiments as in $\boldsymbol{A}$. Data baseline-normalized in experiments before pooling. Values of $p$ show no significant difference between the two pathways. C, LTP in the presence of kainate receptor antagonist UBP-302. Shown is LTP in one 0-LM cell in the continued presence of UBP-302 ( $25 \mu \mathrm{M})$. UBP was washed in 20 min before starting the baseline acquisition. HFS was delivered to one pathway (solid symbols) as shown by schematic and an arrow indicating the time of stimulation. Right, EPSPs (average of 20) in both pathways at different time points. Shown is reconstruction of the cell labeled after repatching (indicated by schematic). Scale bar, $100 \mu \mathrm{m}$. $\boldsymbol{D}$, Shown are normalized mean \pm SEM of five 0 -LM cells studied as in $\boldsymbol{A}$.

of AMPAR antagonists was not sufficient to induce LTP when postsynaptic membrane potential was either hyperpolarized or depolarized indicates that synaptic activation of metabotropic glutamate receptors alone is insufficient to induce LTP. It is also 

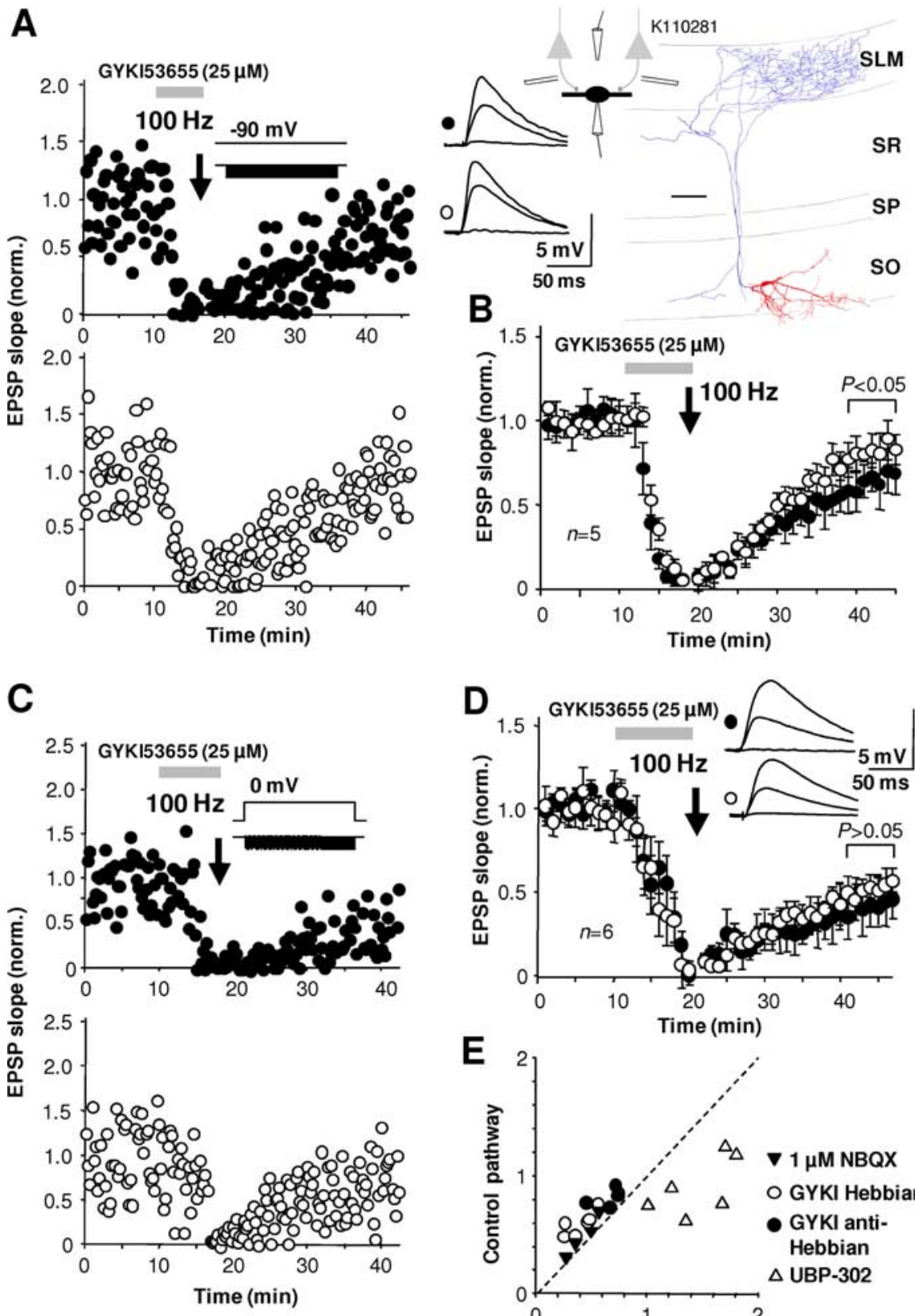

E

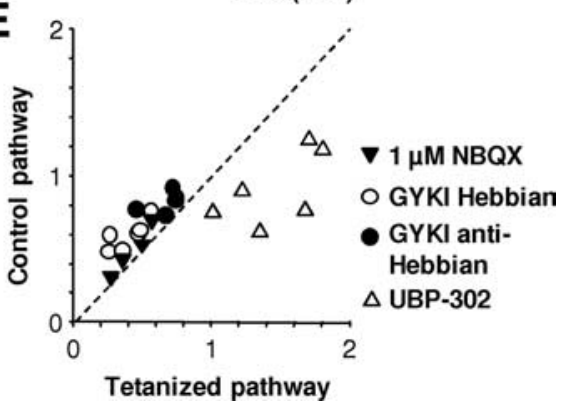

Figure 6. HFS is not sufficient to induce LTP in 0 -LM cells when AMPARs are selectively blocked. $\boldsymbol{A}$, EPSPs in two pathways recorded in an 0-LM cell. After a baseline, EPSPs were blocked by washing in selective AMPAR antagonist, GYKI53655 (25 $\mu \mathrm{M}$; indicated by horizontal bar). HFS ( $100 \mathrm{~Hz}$; arrow) was delivered to one pathway (solid symbols) while membrane potential was clamped to $-90 \mathrm{mV}$. Washout of GYKI started immediately after HFS. Recovery of EPSPs in the tetanized pathway was slightly slower than in the control pathway. Right, Averages of EPSP (20) are shown in the two channels. Shown is a schematic indicating repatching and a reconstruction of same cell. Scale bar, $100 \mu \mathrm{m}$. B, Mean \pm SEM in five 0 -LM cells studied similarly. Value of $p$ shows that recovery in the tetanized pathway (solid symbols) was significantly slower than control pathway EPSP. C, EPSPs in two pathways recorded and blocked by GYKI53655 in one cell as in $\boldsymbol{A}$, but now Hebbian pairing protocol (cell depolarized to $0 \mathrm{mV}$ during HFS as indicated by schematic inset) was delivered to one pathway (solid symbols in the presence of GYKI53655). $\boldsymbol{D}_{\text {, }}$ Mean \pm SEM of similar experiments in six 0-LM cells. Inset, Averaged EPSPs (20) in the two pathways at different stages of the recording. After the washout of the drug, recovery of EPSP in the tetanized pathway was slightly slower, but this difference was not significant. $\boldsymbol{E}$, Summary of the effects of AMPA and the kainate receptor-antagonists on LTP in 0-LM cells. The plot shows baseline-normalized EPSP initial slope recovery in the two pathways in every experiment after the HFS and antagonist washout $(20-25 \mathrm{~min})$.

unclear whether mGluR1 receptor activation by presynaptic tetanization would provide spatially restricted postsynaptic calcium dynamics, which would be required to induce synapse-specific LTP as described here (Goldberg et al., 2003b; Topolnik et al.,
2005; Kullmann and Lamsa, 2008). We suggest that mGluRs have a permissive rather than instructive role in antiHebbian LTP induction (Kullmann and Lamsa, 2008).

Interestingly, when AMPARs were blocked during tetanization, the conditioned pathway recovered less than the control pathway. In these experiments, 25 $\mu \mathrm{M}$ GYKI was used instead of $50 \mu \mathrm{M}$ to improve recovery of EPSPs during the drug washout. Given that this apparent depression was more pronounced when HFS were given at negative potentials, it is possible that it was induced via residual CPAMPAR activation during tetanic stimulation (Laezza and Dingledine, 2004). The mechanisms of LTD in interneurons show extensive heterogeneity, providing multiple candidates to be tested to determine its induction mechanism (McMahon and Kauer, 1997; Laezza et al., 1999; Lei and McBain, 2004). Heterosynaptic potentiation of the control pathway in these experiments cannot be fully excluded either (Cowan et al., 1998).

\section{Contribution of kainate receptors to excitation of $\mathrm{O}-\mathrm{LM}$ cells}

The involvement of kainate receptors in the induction of anti-Hebbian LTP was hypothesized for three reasons. First, kainate receptors can exhibit marked polyamine-dependent inward rectification akin to rectifying AMPA receptors (Bowie and Mayer, 1995; Kamboj et al., 1995). Second, such receptors can also be highly permeable to $\mathrm{Ca}^{2+}$ (Rogawski et al., 2003; Wilding et al., 2005). Third, synaptic kainate receptors are widely expressed in GABAergic interneurons including O-LM cells and can contribute to their recruitment to firing (Bureau et al., 1999; Mulle et al., 2000; Paternain et al., 2000; RodriguezMoreno et al., 2000; Cossart et al., 2002; Yang et al., 2006; Goldin et al., 2007). Although we confirm that kainate receptors contribute to EPSCs evoked in O-LM cells in rat hippocampal slices, they do not appear to play a major role in synaptic excitation of these cells. Moreover, although our experiments suggest that GluR5containing kainate receptors mediate the majority of kainate receptor-mediated synaptic currents, blockade of these receptors did not prevent LTP induction in O-LM cells. Although GluR6-containing receptors have also been reported in hippocampal interneurons, a suitable selective blocker is not available to test whether such receptors also contribute (Mulle et al., 2000; Paternain et al., 2000).

A recent study in mice reported that the majority of synaptic excitation of CA1 O-LM cells is mediated by kainate receptors, 
with a relatively small contribution of AMPARs (Goldin et al., 2007). In contrast, our results show that, in identified O-LM cells in the rat hippocampal CA1 area, synaptic excitation is almost entirely mediated via AMPARs. Kainate receptor-mediated EPSCs were only elicited during repetitive activation of afferents. In agreement with previously reported findings in mice (Goldin et al., 2007), mEPSCs in O-LM cells in the rat showed a wide range of decay time constants. However, mEPSCs showed pharmacologically and biophysically homogeneous properties, being blocked by selective AMPAR antagonists and showing inward rectification. This supports the conclusion that the mEPSCs were mediated via CP-AMPARs and not by kainate receptors, and suggests that their kinetic variability was mainly attributable to electrotonic filtering (McBain and Dingledine, 1993). Unlike O-LM cells in mice, we found no evidence of pure kainate receptor-mediated synaptic events in the rat. The discrepancy might be at least partially explained by species specificity (Lanthorn et al., 1984; Salin et al., 1995).

\section{Characteristic properties of LTP in O-LM cells}

Although long-term plasticity properties in hippocampal interneurons show extensive heterogeneity, the present study shows LTP in O-LM cells to be remarkably uniform with respect to several parameters. First, LTP induction showed a consistent voltage dependence in all studied O-LM interneurons, induced when the postsynaptic membrane potential was hyperpolarized during afferent activity, but unsuccessful at strongly depolarized potential. Second, LTP was restricted to the tetanized afferent pathway, implying synapse specificity. Third, LTP was systematically associated with a reduction in CV of the EPSP, consistent with a presynaptic locus of expression (Edwards et al., 1990). Fourth, LTP was critically dependent on AMPA receptors in all studied O-LM interneurons. An explanation for the consistency may partially stem from the recording method. Perforated-patch recording may be more suitable for LTP studies than the wholecell configuration (Isaac et al., 1996; Lamsa et al., 2005), because this method allows stable and long-lasting recording with minimal disruption of intracellular signaling cascades (Akaike, 1996).

The prevalence and consistency of the plasticity rules at the glutamatergic synapses onto O-LM cells suggest that long-term plasticity properties may be more uniform within individual interneuron types than previously expected. Glutamatergic afferents innervating stratum oriens in which O-LM cell dendrites are located include the local axons of CA1 pyramidal cells, CA3 pyramidal axons, and the alvear pathway of entorhinal afferents. The only known input to O-LM cells is from CA1 pyramidal cells, which form the majority of glutamatergic synapses on this cell type (Blasco-Ibáñez and Freund, 1995), which may explain the relatively uniform synaptic plasticity behavior. However, because most interneuron types receive glutamatergic afferents from several presynaptic loci, we cannot infer that the same patterns of plasticity occur at all synapses (Maccaferri and McBain, 1995).

\section{Conclusions}

Although "horizontal" interneurons in stratum oriens of the hippocampal CA1 area are often studied as a single group of interneurons (for review, see Maccaferri, 2005), they include several cell types in addition to O-LM cells (Klausberger and Somogyi, 2008). Despite the similarity of the somatodendritic shapes of these cells, interneurons in this layer are diverse and fall into several different categories. Each shows unique properties and a characteristic place in the circuitry (Sik et al., 1995; Losonczy et al., 2002; Gulyás et al., 2003; Ganter et al., 2004; Jinno et al., 2007).
Whether other horizontal cell types in s. oriens show similar or different types of long-term synaptic plasticity remains to be studied systematically. Many of the mechanisms of long-term plasticity in interneurons in the hippocampus are still unclear, and to date AMPA/kainate, NMDA, and mGluR1 receptors have been shown to play a role in LTP in nonpyramidal cells in s. oriens (Ouardouz and Lacaille, 1995; Perez et al., 2001; Lamsa et al., 2007a). Sampling across interneuron types could explain some of the heterogeneity reported in previous studies on plasticity in which interneuron types were not identified (for review, see Kullmann and Lamsa, 2008). Heterogeneous properties of synaptic plasticity across interneuron types may reflect a diversity of cell type-specific patterns, which would provide flexibility in the hippocampal inhibitory network.

\section{References}

Akaike N (1996) Gramicidin perforated patch recording and intracellular chloride activity in excitable cells. Prog Biophys Mol Biol 65:251-264.

Ali AB, Thomson AM (1998) Facilitating pyramid to horizontal oriensalveus interneurone inputs: dual intracellular recordings in slices of rat hippocampus. J Physiol 507:185-199.

Alle H, Jonas P, Geiger JR (2001) PTP and LTP at a hippocampal mossy fiber-interneuron synapse. Proc Natl Acad Sci U S A 98:14708-14713.

Angulo MC, Lambolez B, Audinat E, Hestrin S, Rossier J (1997) Subunit composition, kinetic, and permeation properties of AMPA receptors in single neocortical nonpyramidal cells. J Neurosci 17:6685-6696.

Baude A, Nusser Z, Roberts JD, Mulvihill E, McIlhinney RA, Somogyi P (1993) The metabotropic glutamate receptor (mGluR1 alpha) is concentrated at perisynaptic membrane of neuronal subpopulations as detected by immunogold reaction. Neuron 11:771-787.

Bellone C, Lüscher C (2005) mGluRs induce a long-term depression in the ventral tegmental area that involves a switch of the subunit composition of AMPA receptors. Eur J Neurosci 21:1280-1288.

Blasco-Ibáñez JM, Freund TF (1995) Synaptic input of horizontal interneurons in stratum oriens of the hippocampal CA1 subfield: structural basis of feed-back activation. Eur J Neurosci 7:2170-2180.

Bowie D, Mayer ML (1995) Inward rectification of both AMPA and kainate subtype glutamate receptors generated by polyamine-mediated ion channel block. Neuron 15:453-462.

Bureau I, Bischoff S, Heinemann SF, Mulle C (1999) Kainate receptormediated responses in the CA1 field of wild-type and GluR6-deficient mice. J Neurosci 19:653-663.

Buzsáki G, Eidelberg E (1982) Direct afferent excitation and long-term potentiation of hippocampal interneurons. J Neurophysiol 48:597-607.

Catania MV, Bellomo M, Giuffrida R, Giuffrida R, Stella AM, Albanese V (1998) AMPA receptor subunits are differentially expressed in parvalbumin- and calretinin-positive neurons of the rat hippocampus. Eur J Neurosci 10:3479-3490.

Christie BR, Franks KM, Seamans JK, Saga K, Sejnowski TJ (2000) Synaptic plasticity in morphologically identified CA1 stratum radiatum interneurons and giant projection cells. Hippocampus 10:673-683.

Clements JD, Silver RA (2000) Unveiling synaptic plasticity: a new graphical and analytical approach. Trends Neurosci 23:105-113.

Cossart R, Esclapez M, Hirsch JC, Bernard C, Ben-Ari Y (1998) GluR5 kainate receptor activation in interneurons increases tonic inhibition of pyramidal cells. Nat Neurosci 1:470-478.

Cossart R, Epsztein J, Tyzio R, Becq H, Hirsch J, Ben-Ari Y, Crépel V (2002) Quantal release of glutamate generates pure kainate and mixed AMPA/ kainate EPSCs in hippocampal neurons. Neuron 35:147-159.

Cowan AI, Stricker C, Reece LJ, Redman SJ (1998) Long-term plasticity at excitatory synapses on aspinous interneurons in area CA1 lacks synaptic specificity. J Neurophysiol 79:13-20.

Edwards FA, Konnerth A, Sakmann B (1990) Quantal analysis of inhibitory synaptic transmission in the dentate gyrus of rat hippocampal slices: a patch-clamp study. J Physiol 430:213-249.

Egebjerg J, Heinemann SF (1993) $\mathrm{Ca}^{2+}$ permeability of unedited and edited versions of the kainate selective glutamate receptor GluR6. Proc Natl Acad Sci U S A 90:755-759.

Ferraguti F, Klausberger T, Cobden P, Baude A, Roberts JD, Szucs P, Kinoshita A, Shigemoto R, Somogyi P, Dalezios Y (2005) Metabotropic 
glutamate receptor 8-expressing nerve terminals target subsets of GABAergic neurons in the hippocampus. J Neurosci 25:10520-10536.

Frerking M, Malenka RC, Nicoll RA (1998) Synaptic activation of kainate receptors on hippocampal interneurons. Nat Neurosci 1:479-486.

Ganter P, Szücs P, Paulsen O, Somogyi P (2004) Properties of horizontal axo-axonic cells in stratum oriens of the hippocampal CAl area of rats in vitro. Hippocampus 14:232-243.

Geiger JR, Melcher T, Koh DS, Sakmann B, Seeburg PH, Jonas P, Monyer H (1995) Relative abundance of subunit mRNAs determines gating and $\mathrm{Ca}^{2+}$ permeability of AMPA receptors in principal neurons and interneurons in rat CNS. Neuron 15:193-204.

Glickfeld LL, Scanziani M (2006) Distinct timing in the activity of cannabinoid-sensitive and cannabinoid-insensitive basket cells. Nat Neurosci 9:807-815.

Goldberg JH, Yuste R, Tamas G (2003a) $\mathrm{Ca}^{2+}$ imaging of mouse neocortical interneurone dendrites: contribution of $\mathrm{Ca}^{2+}$-permeable AMPA and NMDA receptors to subthreshold $\mathrm{Ca}^{2+}$ dynamics. J Physiol 551:67-78.

Goldberg JH, Tamas G, Aronov D, Yuste R (2003b) Calcium microdomains in aspiny dendrites. Neuron 40:807-821.

Goldin M, Epsztein J, Jorquera I, Represa A, Ben-Ari Y, Crépel V, Cossart R (2007) Synaptic kainate receptors tune oriens-lacunosum moleculare interneurons to operate at theta frequency. J Neurosci 27:9560-9572.

Gulyás AI, Hájos N, Katona I, Freund TF (2003) Interneurons are the local targets of hippocampal inhibitory cells which project to the medial septum. Eur J Neurosci 17:1861-1872.

Hwang TN, Copenhagen DR (1999) Automatic detection, characterization, and discrimination of kinetically distinct spontaneous synaptic events. J Neurosci Methods 92:65-73.

Isaac JT, Hjelmstad GO, Nicoll RA, Malenka RC (1996) Long-term potentiation at single fiber inputs to hippocampal CA1 pyramidal cells. Proc Natl Acad Sci U S A 93:8710-8715.

Jinno S, Klausberger T, Marton LF, Dalezios Y, Roberts JD, Fuentealba P, Bushong EA, Henze D, Buzsáki G, Somogyi P (2007) Neuronal diversity in GABAergic long-range projections from the hippocampus. J Neurosci 27:8790-8804.

Jonas P, Racca C, Sakmann B, Seeburg PH, Monyer H (1994) Differences in $\mathrm{Ca}^{2+}$ permeability of AMPA-type glutamate receptor channels in neocortical neurons caused by differential GluR-B subunit expression. Neuron 12:1281-1289.

Kaiser KM, Lübke J, Zilberter Y, Sakmann B (2004) Postsynaptic calcium influx at single synaptic contacts between pyramidal neurons and bitufted interneurons in layer $2 / 3$ of rat neocortex is enhanced by backpropagating action potentials. J Neurosci 24:1319-1329.

Kamboj SK, Swanson GT, Cull-Candy SG (1995) Intracellular spermine confers rectification on rat calcium-permeable AMPA and kainate receptors. J Physiol 486:297-303.

Klausberger T, Somogyi P (2008) Neuronal diversity and temporal dynamics: the unity of hippocampal circuit operations. Science 321:53-57.

Koh DS, Burnashev N, Jonas P (1995) Block of native $\mathrm{Ca}^{2+}$-permeable AMPA receptors in rat brain by intracellular polyamines generates double rectification. J Physiol 486:305-312.

Köhler M, Burnashev N, Sakmann B, Seeburg PH (1993) Determinants of $\mathrm{Ca}^{2+}$ permeability in both TM1 and TM2 of high affinity kainate receptor channels: diversity by RNA editing. Neuron 10:491-500.

Kullmann DM, Lamsa KP (2007) Long-term synaptic plasticity in hippocampal interneurons. Nat Rev Neurosci 8:687-699.

Kullmann DM, Lamsa K (2008) Roles of distinct glutamate receptors in induction of anti-Hebbian long-term potentiation. J Physiol 586:1481-1486.

Lacaille JC, Mueller AL, Kunkel DD, Schwartzkroin PA (1987) Local circuit interactions between oriens/alveus interneurons and CAl pyramidal cells in hippocampal slices: electrophysiology and morphology. J Neurosci 7:1979-1993

Laezza F, Dingledine R (2004) Voltage-controlled plasticity at GluR2deficient synapses onto hippocampal interneurons. J Neurophysiol 92:3575-3581.

Laezza F, Doherty JJ, Dingledine R (1999) Long-term depression in hippocampal interneurons: joint requirement for pre- and postsynaptic events. Science 285:1411-1414.

Lamsa K, Heeroma JH, Kullmann DM (2005) Hebbian LTP in feed-forward inhibitory interneurons and the temporal fidelity of input discrimination. Nat Neurosci 8:916-924.
Lamsa KP, Heeroma JH, Somogyi P, Rusakov DA, Kullmann DM (2007a) Anti-Hebbian long-term potentiation in the hippocampal feedback inhibitory circuit. Science 315:1262-1266.

Lamsa K, Irvine EE, Giese KP, Kullmann DM (2007b) NMDA receptordependent long-term potentiation in mouse hippocampal interneurons shows a unique dependence on $\mathrm{Ca}^{2+} /$ calmodulin-dependent kinases. J Physiol 584:885-894.

Lanthorn TH, Ganong AH, Cotman CW (1984) 2-Amino-4phosphonobutyrate selectively blocks mossy fiber-CA3 responses in guinea pig but not rat hippocampus. Brain Res 290:174-178.

Lapointe V, Morin F, Ratte S, Croce A, Conquet F, Lacaille JC (2004) Synapse-specific mGluR1-dependent long-term potentiation in interneurones regulates mouse hippocampal inhibition. J Physiol 555:125-135.

Lei S, McBain CJ (2004) Two loci of expression for long-term depression at hippocampal mossy fiber-interneuron synapses. J Neurosci 24:2112-2121.

Le Vasseur M, Ran I, Lacaille JC (2008) Selective induction of metabotropic glutamate receptor 1 - and metabotropic glutamate receptor 5-dependent chemical long-term potentiation at oriens/alveus interneuron synapses of mouse hippocampus. Neuroscience 151:28-42.

Liu SJ, Zukin RS (2007) $\mathrm{Ca}^{2+}$-permeable AMPA receptors in synaptic plasticity and neuronal death. Trends Neurosci 30:126-134.

Liu SQ, Cull-Candy SG (2000) Synaptic activity at calcium-permeable AMPA receptors induces a switch in receptor subtype. Nature 405:454-458.

Losonczy A, Zhang L, Shigemoto R, Somogyi P, Nusser Z (2002) Cell type dependence and variability in the short-term plasticity of EPSCs in identified mouse hippocampal interneurones. J Physiol 542:193-210.

Maccaferri G (2005) Stratum oriens horizontal interneurone diversity and hippocampal network dynamics. J Physiol 562:73-80.

Maccaferri G, McBain CJ (1995) Passive propagation of LTD to stratum oriens-alveus inhibitory neurons modulates the temporoammonic input to the hippocampal CA1 region. Neuron 15:137-145.

Maccaferri G, McBain CJ (1996) Long-term potentiation in distinct subtypes of hippocampal nonpyramidal neurons. J Neurosci 16:5334-5343.

Maccaferri G, Tóth K, McBain CJ (1998) Target-specific expression of presynaptic mossy fiber plasticity. Science 279:1368-1370.

McBain CJ, Dingledine R (1993) Heterogeneity of synaptic glutamate receptors on $\mathrm{CA} 3$ stratum radiatum interneurones of rat hippocampus. J Physiol 462:373-392.

McBain CJ, DiChiara TJ, Kauer JA (1994) Activation of metabotropic glutamate receptors differentially affects two classes of hippocampal interneurons and potentiates excitatory synaptic transmission. J Neurosci 14:4433-4445.

McMahon LL, Kauer JA (1997) Hippocampal interneurons express a novel form of synaptic plasticity. Neuron 18:295-305.

Min MY, Asztely F, Kokaia M, Kullmann DM (1998) Long-term potentiation and dual-component quantal signaling in the dentate gyrus. Proc Natl Acad Sci U S A 95:4702-4707.

Mulle C, Sailer A, Swanson GT, Brana C, O'Gorman S, Bettler B, Heinemann SF (2000) Subunit composition of kainate receptors in hippocampal interneurons. Neuron 28:475-484.

Ouardouz M, Lacaille JC (1995) Mechanisms of selective long-term potentiation of excitatory synapses in stratum oriens/alveus interneurons of rat hippocampal slices. J Neurophysiol 73:810-819.

Paternain AV, Herrera MT, Nieto MA, Lerma J (2000) GluR5 and GluR6 kainate receptor subunits coexist in hippocampal neurons and coassemble to form functional receptors. J Neurosci 20:196-205.

Perez Y, Morin F, Lacaille JC (2001) A hebbian form of long-term potentiation dependent on mGluRla in hippocampal inhibitory interneurons. Proc Natl Acad Sci U S A 98:9401-9406.

Plant K, Pelkey KA, Bortolotto ZA, Morita D, Terashima A, McBain CJ, Collingridge GL, Isaac JT (2006) Transient incorporation of native GluR2-lacking AMPA receptors during hippocampal long-term potentiation. Nat Neurosci 9:602-604.

Racca C, Catania MV, Monyer H, Sakmann B (1996) Expression of AMPAglutamate receptor B subunit in rat hippocampal GABAergic neurons. Eur J Neurosci 8:1580-1590.

Rodriguez-Moreno A, Lopez-Garcia JC, Lerma J (2000) Two populations of kainate receptors with separate signaling mechanisms in hippocampal interneurons. Proc Natl Acad Sci U S A 97:1293-1298. 
Rogawski MA, Gryder D, Castaneda D, Yonekawa W, Banks MK, Lia H (2003) GluR5 kainate receptors, seizures, and the amygdala. Ann N Y Acad Sci 985:150-162.

Rózsa B, Katona G, Kaszás A, Szipöcs R, Vizi ES (2008) Dendritic nicotinic receptors modulate backpropagating action potentials and long-term plasticity of interneurons. Eur J Neurosci 27:364-377.

Salin PA, Weisskopf MG, Nicoll RA (1995) A comparison of the role of dynorphin in the hippocampal mossy fiber pathway in guinea pig and rat. J Neurosci 15:6939-6945.

Sik A, Penttonen M, Ylinen A, Buzsáki G (1995) Hippocampal CA1 interneurons: an in vivo intracellular labeling study. J Neurosci 15:6651-6665.

Somogyi P, Klausberger T (2005) Defined types of cortical interneurone structure space and spike timing in the hippocampus. J Physiol 562:9-26.

Topolnik L, Congar P, Lacaille JC (2005) Differential regulation of metabotropic glutamate receptor- and AMPA receptor-mediated dendritic $\mathrm{Ca}^{2+}$ signals by presynaptic and postsynaptic activity in hippocampal interneurons. J Neurosci 25:990-1001.

Tóth K, McBain CJ (1998) Afferent-specific innervation of two distinct
AMPA receptor subtypes on single hippocampal interneurons. Nat Neurosci 1:572-578.

Wang JH, Kelly P (2001) Calcium-calmodulin signalling pathway upregulates glutamatergic synaptic function in non-pyramidal, fast spiking rat hippocampal CA1 neurons. J Physiol 533:407-422.

Wilding TJ, Huettner JE (1995) Differential antagonism of alpha-amino-3 hydroxy-5-methyl-4-isoxazolepropionic acid-preferring and kainatepreferring receptors by 2,3-benzodiazepines. Mol Pharmacol 47:582-587.

Wilding TJ, Zhou Y, Huettner JE (2005) Q/R site editing controls kainate receptor inhibition by membrane fatty acids. J Neurosci 25:9470-9478.

Williams SR, Mitchell SJ (2008) Direct measurement of somatic voltage clamp errors in central neurons. Nat Neurosci 11:790-798.

Yang EJ, Harris AZ, Pettit DL (2006) Variable kainate receptor distributions of oriens interneurons. J Neurophysiol 96:1683-1689.

Yanovsky Y, Sergeeva OA, Freund TF, Haas HL (1997) Activation of interneurons at the stratum oriens/alveus border suppresses excitatory transmission to apical dendrites in the CA1 area of the mouse hippocampus. Neuroscience 77:87-96. 